\title{
SEARCHING FOR THE EFFECT OF IMMIGRATION ON THE LABOR MARKET
}

\author{
George J. Borjas \\ Richard B. Freeman \\ Lawrence F. Katz
}

Working Paper 5454

\section{NATIONAL BUREAU OF ECONOMIC RESEARCH 1050 Massachusetts Avenue Cambridge, MA 02138 \\ February 1996}

This paper was prepared for presentation at the American Economic Association Session on "Globalization and the U.S. Labor Market," Saturday, January 6, 10:15 AM. We are grateful to Marianne Bertrand for expert research assistance. This paper is part of NBER's research program in Labor Studies. Any opinions expressed are those of the authors and not those of the National Bureau of Economic Research.

(C) 1996 by George J. Borjas, Richard B. Freeman and Lawrence F. Katz. All rights reserved. Short sections of text, not to exceed two paragraphs, may be quoted without explicit permission provided that full credit, including $(\mathcal{O}$ notice, is given to the source. 


\title{
SEARCHING FOR THE EFFECT OF IMMIGRATION ON THE LABOR MARKET
}

\begin{abstract}
We compare two approaches to analyzing the effects of immigration on the labor market and find that the estimated effect of immigration on U.S. native labor outcomes depends critically on the empirical experiment used. Area analyses contrast the level or change in immigration by area with the level or change in the outcomes of non-immigrant workers. Factor proportions analyses treat immigrants as a source of increased national supply of workers of the relevant skill. Cross-section comparisons of wages and immigration in the 1980 and 1990 Censuses yield unstable results casting doubt on the validity of these calculations. Analyses of changes over time for various education groups within regions give negative estimated immigration effects, which increase in magnitude the wider the area covered. Factor proportions calculations show that immigration was somewhat important in reducing the relative pay of U.S. high school dropouts during the 1980s, while immigration and trade contributed much more modestly to the falling pay of high school equivalent workers. The different effects of immigration on native outcomes in the area and factor proportions methodologies appear to result from the diluting effect of native migration flows across regions and failure to take adequate account of other regional labor market conditions in area comparisons.
\end{abstract}

George J. Borjas

Kennedy School Harvard University

Cambridge, MA 02138

and NBER
Richard B. Freeman Department of Economics Harvard University Cambridge, MA 02138 and NBER
Lawrence F. Katz Department of Economics Harvard University Cambridge, MA 02138 and NBER 
In $19806.4 \%$ of the American work force was foreign-born; in 1994, 9.7\% of the work force was foreign-born. A disproportionate number of immigrants are high school dropouts, increasing the supply of less educated workers and potentially contributing to the observed decline in their relative pay. Over the same period, imports brought the output of less skilled foreign workers into the U.S., while the export of skill-intensive products raised the demand for skilled workers, further altering the skill content of U.S. labor supply/demand.

There are two ways to examine the effect of immigration on labor market outcomes. Exploiting the fact that immigration is geographically concentrated, area analyses contrast the level or change in immigration by area with the level or change in the earnings (or employment) of non-immigrant workers. Area studies have generally found that immigration has had only a slight effect on native outcomes (George Borjas, 1994): native earnings or employment do not differ much between the gateway areas that receive immigrants and other parts of the country. Factor proportions analyses take a general equilibrium perspective, treating immigrants as a source of increased national supply of workers of the relevant skill, and treating trade as a source of changes in the supply of skills as well. It applies an elasticity of substitution to estimate the effect of these changes in labor supply on relative wages. These studies have found that immigration and trade contributed moderately to the rise in U.S. earnings inequality during the 1980s (e.g., George Borjas, Richard Freeman and Lawrence Katz, 1992).

This paper compares the area and factor proportions approaches to estimating the effects of immigration on the labor market. We find that cross-section area comparisons in the 1980 and 1990 Censuses of Population do not yield stable estimates of the effect of immigrants on male earnings and yield sufficiently different effects on female than on male earnings to make us leery of interpreting these results as reflecting the effect of immigration on wages. 
Comparisons of changes in immigration flows and in native wages across areas and education groups give quite different results: when we control for regional conditions, we obtain negative relations between immigration-induced changes in supply and native wages. Our factor proportions estimates of the effect of immigrants and trade show that immigration contributed more to the decline in the relative earnings of high school dropouts than trade, while both modestly reduced the earnings of high school workers relative to college workers.

\section{The Area Approach}

The area approach to the study of the effects of immigration on the job market exploits the high concentration of immigrants in gateway cities or states. In $199260 \%$ of legal immigrants came to California or New York and an additional 20\% entered New Jersey, Texas, Illinois, and Florida (U.S. Department of Commerce, 1994, table 10). Given an exogenous flow of immigrants to areas that is uncorrelated with levels/changes in native labor supply or labor demand among the areas; and sufficient time for the wages of native workers to adjust to the change in supply, comparisons of wages between immigrant-intensive and non-immigrant-intensive areas should yield stable valid estimates of the effect of immigration on native wages.

Table 1 presents our estimates of the cross-section effect of immigration on log weekly earnings of natives using the Public Use samples of the 1980 and 1990 Censuses of Population. Our calculations are based on a 1/100 random sample of native workers and on a 5/100 random sample of immigrant (foreign-born) workers. In each Census we restricted our analysis to persons aged 18-64 not residing in group quarters, employed in the civilian sector in the calendar year prior to the Census and not self-employed. We estimated the following cross-section regressions separately for native males and females: 


$$
\log \mathrm{w}_{\mathrm{ijk}}=\alpha \mathrm{AGE}_{\mathrm{i}}+\beta \mathrm{EDUC}_{\mathrm{i}}+\gamma(\mathrm{I} / \mathrm{N})_{\mathbf{k}}+\mathrm{e}_{\mathrm{ijk}},
$$

where $w_{i j k}$ is the weekly earnings of person $i$ in education group $j$ in area $k$; AGE is a vector of age dummies $(18-24 ; 25-34 ; 35-44 ; 45-54 ; 55-64)$ that transforms our data into age-adjusted weekly earnings; EDUC is a vector of dummies for the education group (high school dropout; high school graduate; some college; college graduate or more); I/N measures the ratio of immigrants to natives in the relevant area. In line 1 the measure is simply the ratio of immigrants to natives (including the self-employed) in the metropolitan area, irrespective of the skill level of the two groups. In line 2 the measure takes account of skills: it is the ratio of immigrants to natives in the natives' education group and area, adjusted for their annual hours of work.

The 1980 cross section for males shows an insignificant effect of the increased supply due to immigrants on native wages. This estimate is less negative than the cross section estimate for low skilled natives in Joseph Altonji and David Card (1991) for a much smaller set of areas, but has the same sign. But the 1990 cross-section yields positive coefficients of immigration on native males. The changes in coefficients over time suggest that the cross-section calculations are dubious structural relations of the effect of immigrants on native wages. One possible reason for the different relations over time is that, for exogenous reasons, demand changed markedly across regions. The 1980s were a period of economic boom in the coastal areas that receive most immigrants and of Rust-Belt problems in many interior areas.

The regressions in table 1 show that women's wages are positively related to the immigrant/native ratios, with, a larger coefficient in 1990 than in 1980. Altonji and Card also found a significant positive cross section relation between women's wages and immigration in 1980. Regressions that pool both genders yield positive coefficients in both 1980 and 1990 . 
The changed sign in the male regressions and the positive coefficients in the female regressions suggest there may be omitted area variables correlated with wages and immigration.

The natural way to address this problem is to compare changes in native wages within an area over time. Table 2 presents such an analysis, with the observations differentiated by area and education. We estimated wages for an area-education group by regressing the $\ln$ weekly earnings on dummy variables for age and gender and area-education group in each Census separately. The difference between the coefficients on the area-education dummy variables in the 1980 and 1990 Censuses provides our estimate of the change in area-education wages $\left(\mathrm{dlnw}_{\mathrm{jk}}\right)$. To estimate the impact of immigrants on the earnings of natives in area $\mathrm{k}$ and education group $\mathrm{j}$ we fit the following first-difference model:

$$
d \ln w_{j k}=\gamma d(I / N)_{j k}+\delta Z_{j k}+e_{j k}
$$

where $d(I / N)_{j k}$ is the change in the ratio of immigrants to natives for that group; and $Z_{j k}$ consists of other regressors. To see if the extent of geographic coverage affects the results, we present regressions for metropolitan areas, states, and the nine major regions with and without both area dummy variables, to control for area specific changes in labor demand, and education variables, to control for national changes in demand for workers by education group.

Each coefficient in the table is from a separate regression. The .0937 in line 1, column 1 shows that a .10 change in the ratio of immigrants to natives by metropolitan area and education was accompanied by a $.009 \mathrm{ln}$ point increase in the wages of the relevant group. All of the coefficients in column 1 , which contains neither area nor education group dummies, are positive. But inclusion of area fixed effects in column 2 turns the coefficients negative. Education groups who had particularly large immigration-induced increases in supply in an area 
also had large falls in pay relative to other education groups in that area. Column 3 controls for education but not for area: if some of the potential negative effect of immigration on the wages of an education group affect that group nationwide, the coefficients on immigration should become more positive, and this is what we find. Column 4 adds area variables, and this turns the coefficients to near zero or negative. We conclude that controlling for local labor market conditions is critical in estimating the effect of immigration on native wages.

There is another important pattern in the coefficients summarized in table 2 . As the geographic area covered widens, the coefficient on the change in immigrant/native ratios tends to become less positive or more negative. This suggests that the results depend not only on the controls in the regressions but also on the geographic area covered. The implication is that if we looked over a wider area, the nation, we would find greater depressant effects of immigration than if we look at smaller metropolitan areas. Why might this be?

There are two possible explanations. One has considerable empirical support, while the other has not received much attention. The first is that the migration of native workers responds to immigration-induced changes in outcomes, so that the immigrant/native ratio overstates the immigration-induced increase in supply in any locale. There is much evidence for such a pattern. Randall Filer (1991) reports a negative correlation between immigration and native outmigration across metropolitan areas in the 1980 Census. William Frey (1995) finds what seems to be an even stronger negative relation in the 1990 Census. Our investigation of native worker migration shows that it is primarily less educated natives whose location decisions respond negatively to immigrants. If native migration responses are sufficiently large over the relevant period, comparisons of small areas will mask the true effect of immigrants on native wages. 
The second possible explanation is that capital may respond to immigration-induced changes in labor supply. While no one has shown that investment in, say the apparel industry in Los Angeles or New York, has been driven by the supply of immigrants, if this were the case, it would partially offset the effects of immigration on native outcomes in those areas.

\section{The Factor Proportions Approach}

The factor proportions approach to seeing how immigration affects the job market assumes that the effects of immigration and trade are sufficiently diffused across areas due to native migration or capital responses that it is best to examine the effect of immigration through its effect on the national supplies of labor with different skills. A factor proportions analysis of the effects of immigration and trade on native wages requires estimates of the changed number of immigrants with different levels of skill; the implicit change in labor supply due to net trade; and of elasticities of relative wages to relative labor supplies.

We obtain the number of immigrants from the 1980 and 1990 Censuses of Population. One problem with these data is that they include some but not all illegal immigrants. A second issue is that immigrants with a given level of schooling may be imperfect substitutes for natives with the same nominal level. Furthermore the change in the Census education question between 1980 and 1990 creates a classification problem; this change led us to calculate changes in the total supply of workers by education group from 1980 to 1990 using the consistent Current Population Survey data. To estimate the effect of trade on the skill composition we estimated how many workers of different skills would be demanded under the counterfactual that net trade by industry did not change over this period. To transform changes in net trade into changes in implicit labor supply we used labor input coefficients based on the average share of workers with 
different levels of education by industry for 1979 to 1991 . This implies trade affected the skill composition of production through input coefficients from roughly the mid-1980s.

Table 3 shows our estimates of the change in labor supply resulting from immigration and net imports of manufactured goods for high school dropouts, high school graduates, those with some college, and for college graduates; and for three more aggregated groups: all workers with 12 or more years of schooling and high school and college equivalents, as defined in Katz and Murphy (1992). The table shows that immigration disproportionately increased the labor supply of high school dropouts. The implicit labor-supply increasing effects of trade are also concentrated among the less educated. The final column of table 3 shows the combined contribution of immigration and trade to the 1980-1990 changes in labor supply.

How much might these changes in labor supply have altered the wages of the various groups? We concentrate on two comparisons: high school dropouts versus all other workers; and high school equivalents versus college equivalents. The immigration/trade induced change in the ln supply of high school dropouts relative to other workers from 1980 to 1990 was .120, while the immigration/trade induced change in the ln supply of high school relative to college equivalents was .023 . We multiplied these changes by estimated elasticities of relative wages to relative supplies from Borjas, Freeman, and Katz (1992): .322 for dropouts/other workers; .709 for high school/college equivalents. These yield effects of immigration and trade on relative wages of $-.039 \ln$ points for dropouts/other workers and of $-.016 \ln$ points for high school/college equivalents. The total change in relative wages for natives in these composite groups from 1980 to 1990 (based on ln earnings regressions with controls for age and sex) were -.08 for high school dropouts/all workers and -.18 for high school/college graduates. The influx 
of less educated immigrants dominates the calculation for high school dropouts, whereas trade and immigration have similar effects in the calculation for high school versus college equivalents. Even with the influx of less skilled workers through immigration and trade, the total supply of high school dropout workers relative to all other workers fell in the U.S. by .456 In points; the decline in native high school dropout workers has been very large.

\section{Conclusion}

The estimated effect of immigration on native labor outcomes depends critically on the empirical experiment used to assess immigration. Our cross section comparisons of wages and immigration in the 1980 and 1990 Censuses yield unstable results which casts doubt on the validity of these calculations. Analyzing changes over time for various education groups within regions gives negative estimated immigration effects, which increase in magnitude the wider the area covered. Evidence that native migration responds to immigrant flows suggest that area comparisons understate the potential adverse effect of immigration-induced increases in labor supply on native wages. Our factor proportions calculations show that immigration has been important in reducing the pay of high school dropouts, while immigration and trade have contributed modestly to the falling pay of high school equivalent workers. It is possible that the different effects of immigration on native outcomes in the area and factor proportions methodologies may be due to the diluting effect of native migration flows across regions and failure to take adequate account of other regional labor market conditions in area comparisons. 


\section{References}

Abowd, John. "Appendix: The NBER Immigration, Trade, and Labor Markets Data Files," in J. Abowd and R. Freeman, eds., Immigration. Trade. and the Labor Market. Chicago: University of Chicago Press, 1991, pp. 407-21.

Altonji, Joseph and David Card. "The Effects of Immigration on the Labor Market Outcomes of Less-Skilled Natives," in J. Abowd and R. Freeman, eds., Immigration. Trade, and the Labor Market. Chicago: University of Chicago Press, 1991, pp. 201-34.

Borjas, George J. "The Economics of Immigration." \ournal of Economic Literature, December 1994, 32(4), pp. 1667-1717.

Borjas, George J., Richard B. Freeman, and Lawrence F. Katz. "On the Labor Market Effects of Immigration and Trade," in G. Borjas and R. Freeman, eds., Immigration and the Work Force. Chicago: University of Chicago Press, 1992, 213-44.

Filer, Randall. "The Effect of Immigrant Arrivals on Migratory Patterns of Native Workers," in G. Borjas and R. Freeman, eds., Immigration and the Work Force. Chicago: University of Chicago and NBER, 1992, 245-69.

Frey, William. "Immigration and Internal Migration 'Flight' from U.S. Metropolitan Areas: Toward a New Demographic Balkanisation. Urban Studies, 1995, 32(4-5), pp. 733-57.

Katz, Lawrence F. and Kevin M. Murphy. "Changes in Relative Wages, 1963-1987: Supply and Demand Factors." Quarterly Journal of Economics, February 1992, 107(1), pp. 35-78.

Sachs, Jeffrey and Howard Shatz. "Trade and Jobs in U.S. Manufacturing." Brookings Papers on Economic Activity, 1994, (1), pp. 1-84.

U.S. Department of Commerce. Statistical Abstract of the United States: 1994. Washington, DC: U.S. Government Printing Office, 1994. 
TABLE 1

\section{CROSS-SECTION IMPACT OF IMMIGRATION ON NATIVE WAGE (Dependent Variable $=$ Ln Weekly Wage)}

Independent Variable
Male Natives

1980

(.0813)

$-.0119$

(.0410)

Education Group $k\left(j / N_{j}\right.$

Sample Size
1990

.2869

$(.0721)$

.4525

(.0941)

1980

.2876

(.0621)

(.0293)

299,202

268,649
.5588

(.1059)

.2865

(.0622)

288,620

NOTES: Standard errors are reported in parentheses. The cross-section regressions also include a vector of dummy variables indicating the worker's age (18-24, 25-34, 35-54, or 55-64 years old) and educational attainment (high school dropout, high school graduate, some college, or college graduate). The sample is restricted to native workers who reside in one of the 236 metropolitan areas that can be matched in the 1980 and 1990 Censuses. 
TABLE 2

IMPACT OF IMMIGRATION ON NATIVE LN WAGE, FIRST-DIFFERENCE REGRESSIONS

\begin{tabular}{|c|c|c|c|c|c|}
\hline \multirow[b]{2}{*}{$\begin{array}{l}\text { Independent Variable/ Geographic } \\
\text { Region }\end{array}$} & \multicolumn{4}{|c|}{ Regression } & \multirow[b]{2}{*}{$\begin{array}{l}\text { Sample } \\
\text { Size }\end{array}$} \\
\hline & (1) & (2) & (3) & (4) & \\
\hline $\begin{array}{l}\text { Change in Relative Number of } \\
\text { Immigrants in Metropolitan Area } \\
j \text { and Education Group } k\end{array}$ & $\begin{array}{l}.0937 \\
(.0269)\end{array}$ & $\begin{array}{l}-.1066 \\
(.0326)\end{array}$ & $\begin{array}{l}.1916 \\
(.0400)\end{array}$ & $\begin{array}{l}.0012 \\
(.0125)\end{array}$ & 944 \\
\hline $\begin{array}{l}\text { Change in Relative Number of } \\
\text { Immigrants in State } j \text { and } \\
\text { Education Group } k\end{array}$ & $\begin{array}{l}.1089 \\
(.0747)\end{array}$ & $\begin{array}{l}-.1751 \\
(.0589)\end{array}$ & $\begin{array}{l}.2489 \\
(.1050)\end{array}$ & $\begin{array}{l}-.0369 \\
(.0120)\end{array}$ & 204 \\
\hline $\begin{array}{l}\text { Change in Relative Number of } \\
\text { Immigrants in Region } j \text { and } \\
\text { Education Group } k\end{array}$ & $\begin{array}{l}.0199 \\
(.0853)\end{array}$ & $\begin{array}{l}-.2058 \\
(.0805)\end{array}$ & $\begin{array}{l}.1984 \\
(.1053)\end{array}$ & $\begin{array}{l}-.0432 \\
(.0187)\end{array}$ & 36 \\
\hline $\begin{array}{l}\text { Includes Education Fixed Effects } \\
\text { Includes Area Fixed Effects }\end{array}$ & $\begin{array}{l}\text { No } \\
\text { No }\end{array}$ & $\begin{array}{l}\text { No } \\
\text { Yes }\end{array}$ & $\begin{array}{l}\text { Yes } \\
\text { No }\end{array}$ & $\begin{array}{l}\text { Yes } \\
\text { Yes }\end{array}$ & \\
\hline
\end{tabular}

NOTES: Standard errors are reported in parentheses. To calculate the dependent variable in the first-difference regressions, we estimated a vector of fixed-effects in each cross-section giving the adjusted in weekly earnings of an education group in the relevant geographic area (metropolitan area, state, or region). This regression controls for age and gender. The dependent variable in the first-difference regression is the difference in these fixed effects between 1990 and 1980 . 
EFFECTS OF RMMIGRATION AND TRADE

ON LABOR SUPPLY BY EDUCATION, 1980-90

\begin{tabular}{ccccc}
$\frac{\text { Immigrants }}{\text { Natives }}\left(\frac{\mathrm{I}}{\mathrm{N}}\right)$ & $\frac{\text { Net Imports }}{\text { Natives }}\left(\frac{\mathrm{T}}{\mathrm{N}}\right)$ & $\Delta \ln \left(1+\frac{\mathrm{I}+\mathrm{T}}{\mathrm{N}}\right)$ \\
\hline 1980 & 1990 & 1980 & 1990 & $1980-1990$ \\
\hline .122 & .262 & .006 & .029 & .135 \\
.044 & .061 & -.001 & .005 & .021 \\
.058 & .069 & .000 & -.005 & .005 \\
.075 & .097 & .005 & -.008 & .009 \\
.055 & .073 & .001 & -.001 & .015 \\
.065 & .094 & .001 & .007 & .031 \\
.072 & .091 & .004 & -.007 & .008
\end{tabular}

Dropouts $(<12)$

High School (12)

Some College (13-15)

College (16+)

High School plus (12+)

High School Equivalents

College Equivalents

Notes: The immigrant and native counts for :980 and 1990 are weighted by annual hours worked in 1979 and 1989 respectively. The sample includes workers aged 18 to 64 years from the 5\% Public Use Microsamples (PUMS) of the 1980 and 1990 Censuses of Population. High school and college equivalents are defined as in Katz and Murphy (1992).

The data used on net imports (imports minus exports) covers trade in manufactures. We estimate net imports per native by education group using Method II of Borjas, Freeman, and Katz (1992) with adjustments for aggregate trade balance as described in Katz and Murphy (1992). The implicit labor supply in exports to industry $i$ in year $t$ is allocated to skill group $j$ using the average proportion of all workers (production and nonproduction) in industry $i$ in the jth skill group $\left(a_{i j}\right)$ for the 1979 to 1991 period where $a_{i j}$ is estimated from the full Current Population Survey Annual Outgiong Rotation Group files covering 1979 to 1991 . The implicit labor supply in imports is allocated on the basis of the average skill distribution of production workers in each industry over 1979 to 1991 . Trade flows are allocated to three-digit Census of Population industries using 1980 data from the NBER Trade Data Files, described in Abowd (1991), and 1990 data assembled by Sachs and Shatz (1994). 